\title{
Role of Knowledge, Skills and Peer Support for Early Recovery of COVID-19 Positive Rescuers
}

\section{Rizwan Naseer, Yasir Riaz Gillani, Mohsin Durrani}

To Link this Article: http://dx.doi.org/10.6007/IJARBSS/v11-i2/8781

DOI:10.6007/IJARBSS/v11-i2/8781

Received: 21 December 2020, Revised: 17 January 2021, Accepted: 30 January 2021

Published Online: 12 February 2021

In-Text Citation: (Naseer et al., 2021)

To Cite this Article: Naseer, R., Gillani, Y. R., \& Durrani, M. (2021). Role of Knowledge, Skills and Peer Support for Early Recovery of COVID-19 Positive Rescuers. International Journal of Academic Research in Business and Social Sciences, 11(2), 294-301.

Copyright: (c) 2021 The Author(s)

Published by Human Resource Management Academic Research Society (www.hrmars.com) This article is published under the Creative Commons Attribution (CC BY 4.0) license. Anyone may reproduce, distribute, translate and create derivative works of this article (for both commercial and non-commercial purposes), subject to full attribution to the original publication and authors. The full terms of this license may be seen at: http://creativecommons.org/licences/by/4.0/legalcode

Vol. 11, No. 2, 2021, Pg. 294 - 301

Full Terms \& Conditions of access and use can be found at http://hrmars.com/index.php/pages/detail/publication-ethics 


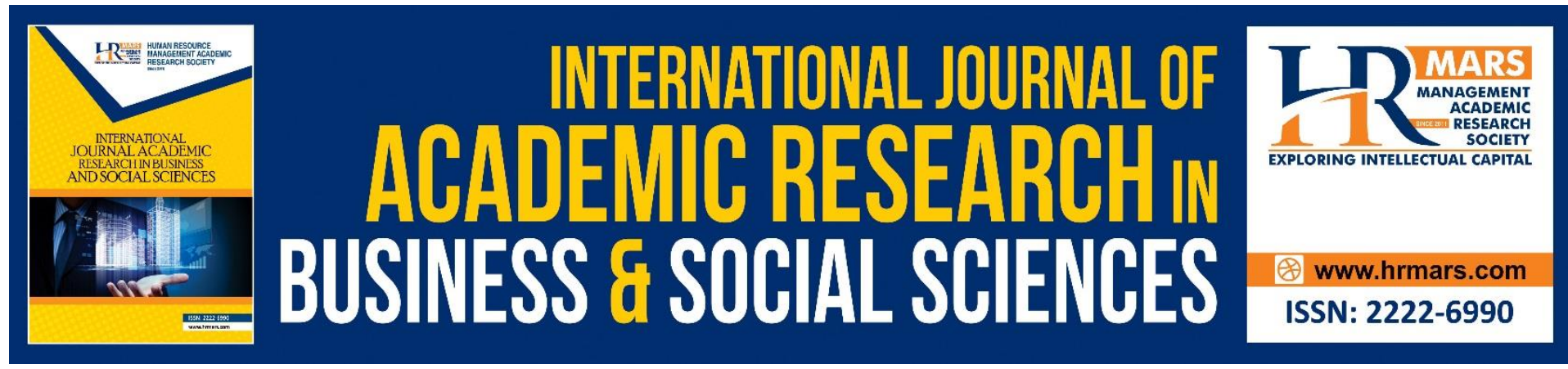

\title{
Role of Knowledge, Skills and Peer Support for Early Recovery of COVID-19 Positive Rescuers
}

\author{
Dr. Rizwan Naseer, Yasir Riaz Gillani, Mohsin Durrani \\ Punjab Emergency Service Rescue 1122 \\ Email: eoresearch1122@gmail.com
}

Background: The Punjab Emergency Service of Pakistan has established field hospital for triage the patients and responded 12625 corona patients for shifting to hospitals and quarantine centers followed by 1838 corona burials. During field operation more than 70 rescuers were also infected, this study explores the factors which were contributed for early recovery.

Method: This survey/field study was carried out among the COVID-19 infected operational staff from February, 2020 to August, 2020 during the first active wave in the country. During this survey 40 rescuers were interviewed by structured questionnaire and the obtained responses were analyzed.

Result: Out of total 40 rescuers, all were male. The median age was $26-35$ years ( $80 \%)$. Among the infected rescuers $95 \%$ did not have any pre-existing co-morbidities. The most common symptoms were Highest Temperature (75\%), Sore Throat (75\%), Cough (68\%), psycho-social factor i.e. Positive behavior (95\%), exercise (27\%), prayer (57\%), learned skills (85\%), professional knowledge (82.5\%) and peer support (70\%) were contributed.

Conclusion: Organizational knowledge and skills along with other psychosocial factors like peer support, positive behavior have contributed for early recovery of the Rescuers.

Keywords: Punjab Emergency Service, Rescuers, COVID-19, First Responders.

\section{Introduction}

The World Health Organization (WHO) declared Coronavirus disease 2019(COVID-19) as a pandemic on $11^{\text {th }}$ March, 2020 which was started from Wuhan City, China in December, 2019 (Novel, 2020). In majority of cases, it has been observed that the infection starts from mild illness and turned toward severe pneumonia that leads to acute respiratory disorder which is fatal for health. The pandemic of Coronavirus infected more than 6.7 million people of the world also having 0.4 million deaths globally till date. The first couple of cases of Coronavirus were confirmed in Karachi and Islamabad on $26^{\text {th }}$ February, 2020 (Ali, Shah, \& Siddiqui, 2020). Upcoming 15 days confirmed 20 more cases that are found 14 in Sindh, 5 in Gilgit and 01 in Baluchistan. The major cause of infection was foreign traveling history as the patients were recently visiting back from Iran, Syria and London. The Health Authorities conduct 471 samples having $20(4.25 \%)$ confirmed positive cases till $12^{\text {th }}$ March, 2020 (MALIK \& Javed, 2020). As the Punjab Emergency Service, Rescue 1122 took initiative to shift the infected patients from homes to hospitals and quarantine centers. Meanwhile, in this process some of 
the operational and administration individuals of the service also got infected from the pandemic and become sick due to the disease. However, it has been observed that the healing period of these individuals was rapid as compare to the other people.

\section{Rationale of the Study}

Rescue 1122 is an outstanding service that is providing lifesaving services to the people of Punjab. As the whole world was suffering due to the coronavirus disease and there was a sever life threat not only to the lives of the general public but also to the paramedics who were performing their professional duties during this pandemic. The operational staff (rescuers) of the Punjab Emergency Service, like the rest of the world, were also infected during their shifting of the patients but it has been observed that their healing process and period was rapid, as compare to the general public.

The aim of this study is to know the facts and techniques that the rescuers used during the period of their disease as how they rapidly overcome on this disease.

\section{Methodology}

This survey study was conducted through random sampling and a specific Performa that was designed and emailed to them also informed them about the purpose of the study through telephonic communication, to know the experience of the employees of Punjab Emergency Service, Rescue 1122 operational staff who were performing their duties during the pandemic and got affected through this life-threatening virus. Initially, this study is conducted between the field staff only who were performing duties on ambulances and are in close contact with the suspected or probable COVID-19 cases and felt fever, cough or sore throat during their professional duties. Later on, the staff from control room and administration sections were also involved in this study. The staff was enlisted to do the Coronavirus test during their quarantine period, usually after 14 days of their quarantine period to know about their current health status, as they are recovered from the COVID-19 or they need more care and treatment.

\section{Results}

Present study explores the socio economic impact of Coronavirus diseases on the healthcare workers of Punjab Emergency Service during the performing of their professional duties and shifting of the infected patients into hospitals and quarantine centers in district Punjab. The results from the data are as under. 


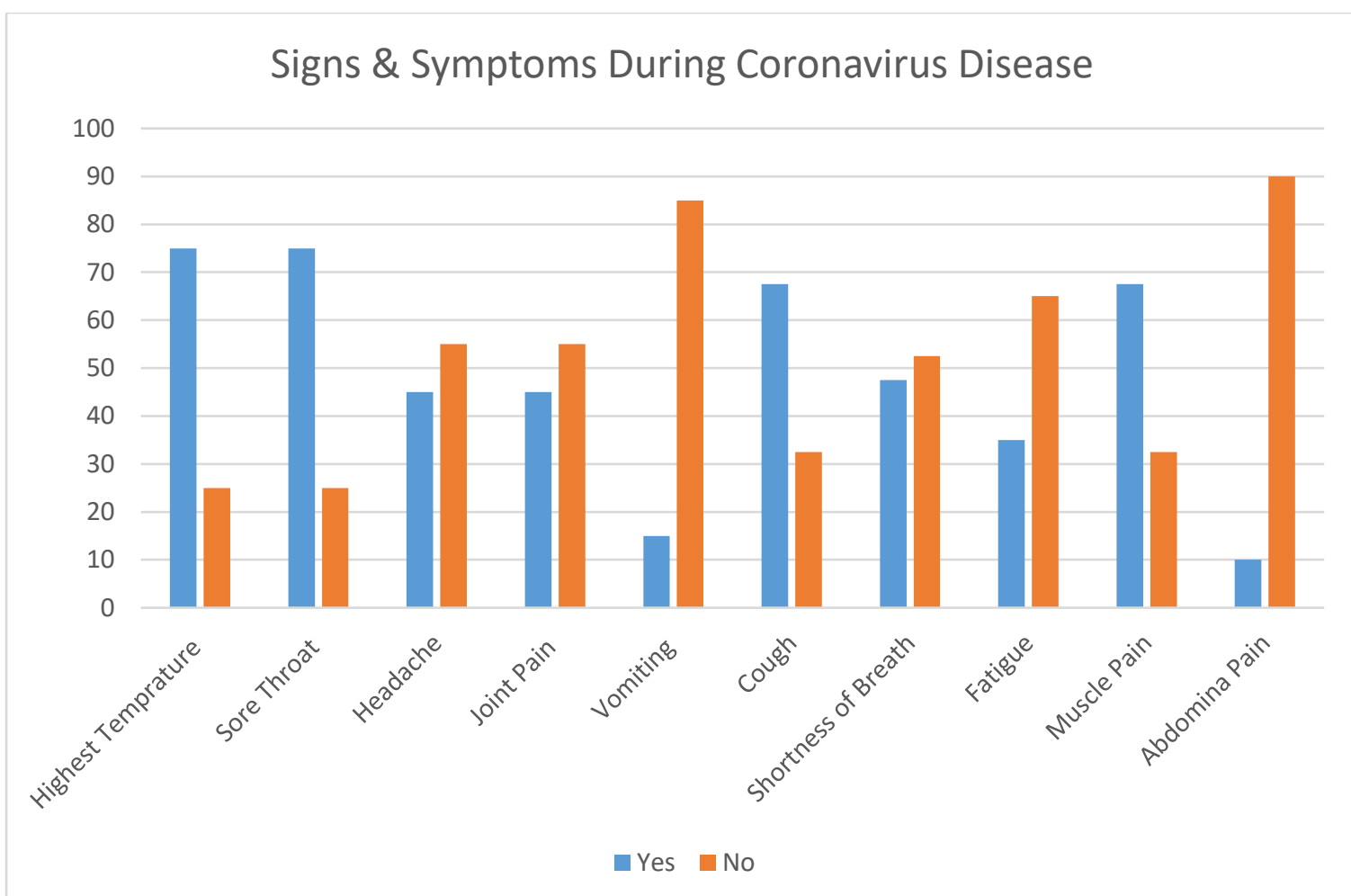

The results have shown that Highest Temperature (75\%), Sore Throat (75\%), Cough (68\%) and Muscle Pain (68\%) were the prominent symptoms that the rescuers had faced during the time of their disease and they all successfully recover from this life threatening disease by adopting various other strategies that make the healing process fast and no life-loss has been observed from all the infected rescuers.

As there is no authentic medicine has yet been discovered by the WHO or other Healthcare Institutions so the single dependency on medicine is not the only way out. Therefore, various techniques/therapies have been practiced by the patients. Same is happened in Punjab Emergency Service and it has been observed that these simple techniques are beneficial for the Corona patients. The most important technique is Positive Behavior (95\%) that keep the nervous system of the patient at normal level which helps them to stay away from anxiety and negativity. The second technique is Skills (85\%) that the rescuers use during their professional duties to provide the pre-hospital care to the victims. Also the Professional Knowledge (82.5) that they learned during their training period at Emergency Services Academy also helped them to overcome the disease. Peer Support (70\%) is also of parimportance, as it helps the patient from psychological shut-down and provide encourage and support for quick recovery.

A total 40 coronavirus affected rescuers of the Punjab Emergency Service had participated in this study who were randomly selected from the total number of rescuers. The main proportion of the reported coronavirus patients $(27 \%)$ were the drivers LTV who had performed transportation duties during the pandemic, also there were other designations like RSO, SI, FDI, EMT, CTWO, etc. 


\begin{tabular}{|c|c|c|c|c|c|}
\hline \multirow{2}{*}{ Staff } & Field Staff & \multicolumn{2}{|c|}{ Office Staff } & \multicolumn{2}{|c|}{ Technical Staff } \\
\hline & $57.5 \%$ & \multicolumn{2}{|c|}{$35.0 \%$} & & $7.5 \%$ \\
\hline \multirow{2}{*}{$\begin{array}{l}\text { Experience in } \\
\text { Service }\end{array}$} & 1-3Years & 4-6 Years & \multicolumn{2}{|c|}{ 7-10 Years } & Above 10 \\
\hline & $7.5 \%$ & $20.0 \%$ & & & $35.0 \%$ \\
\hline \multirow{2}{*}{ Marital Status } & \multicolumn{2}{|c|}{ Married } & \multicolumn{3}{|c|}{ Single } \\
\hline & \multicolumn{2}{|c|}{$85.0 \%$} & \multicolumn{3}{|c|}{$15.0 \%$} \\
\hline \multirow{2}{*}{ Age } & $18-25$ Years & \multicolumn{2}{|c|}{ 26-35 Years } & \multicolumn{2}{|c|}{ 36-50 Years } \\
\hline & $2.5 \%$ & & & \multicolumn{2}{|c|}{$17.5 \%$} \\
\hline \multirow{2}{*}{$\begin{array}{c}\text { Previous Medical } \\
\text { History }\end{array}$} & \multicolumn{2}{|c|}{ No History } & \multicolumn{3}{|c|}{ Kidney Pain } \\
\hline & \multicolumn{2}{|c|}{$97.5 \%$} & \multicolumn{3}{|c|}{$2.5 \%$} \\
\hline
\end{tabular}

Table-2: The Table-2 has shown the experience of the infected rescuers from coronavirus i.e. 01-03 Years (7.5\%), 4-6 Years (20.0\%), 7-10 Years (37.5\%), and above 10 Years $(35.0 \%)$. The main proportion reflects that the rescuers having 7-10 Years professional experience were the most infected during this pandemic as they prefer to step forward due to their field knowledge and performed exemplary duties in front of the newly joined rescuers.

Table-3: As the results shows that the majority of the participants (85\%) were married and only (15\%) were the single.

Table-4: also explore about the age group of the victims of coronavirus i.e. 18-28 (2.5\%), $26-35(80.0 \%)$, and $36-50(17 \%)$. The main proportion reflects that the youth and ripe age individuals who are infected from the pandemic of Coronavirus.

\begin{tabular}{|c|c|}
\hline \multicolumn{2}{|c|}{ Do you get peers support during coronavirus? } \\
\hline & Percentage \\
\hline Yes & 70.0 \\
\hline No & 30.0 \\
\hline Total & 100.0 \\
\hline
\end{tabular}

Table 2: shows the importance of Peers support in the recovery from COVID-19. It shows that $70 \%$ of the rescuers get peers support to recover fast from this disease.

\begin{tabular}{|c|c|}
\hline Does your professional knowledge help to get fast recovery from disease? \\
\hline & Percentage \\
\hline Yes & 82.5 \\
\hline No & 17.5 \\
\hline Total & 100.0 \\
\hline
\end{tabular}

Table 3: is related to the professional knowledge of the rescuers that what they learn from the organization during their learning period and implement all that knowledge in the field operations. This professional knowledge (82.5\%) help them to get fast recovery from the disease. 


\begin{tabular}{|c|c|}
\hline \multicolumn{2}{|c|}{ Do you take self-medication? } \\
\hline Yes & Percentage \\
\hline No & 30.0 \\
\hline 14.00 & 67.5 \\
\hline Total & 2.5 \\
\hline
\end{tabular}

Table 4: taking medicine for the healing process is the foundation in cure. But in some cases, it has been observed that some patients do self-medication for themselves. The results have shown that $68 \%$ rescuers do not use the self-medication and they only use the doctor's advice for their medication. Also $30 \%$ employees do self-medication as the part of healing process.

\begin{tabular}{|c|c|}
\hline \multicolumn{2}{|c|}{ Do you transfer your disease to your family member? } \\
\hline & Percentage \\
\hline Yes & 10.0 \\
\hline No & 90.0 \\
\hline Total & 100.0 \\
\hline
\end{tabular}

Table 5: COVID-19 is a transferable disease that could easily transferable from one person to the other but the results have shown that the rescuers were well aware/prepared from the pandemic and $90 \%$ of the patients do not transfer their disease to their family members. Only $10 \%$ have transfer their disease to their family members.

\begin{tabular}{|c|c|}
\hline \multicolumn{2}{|c|}{ You think that positive behavior helps in recovery? } \\
\hline & Percentage \\
\hline Yes & 95.0 \\
\hline No & 5.0 \\
\hline Total & 100.0 \\
\hline
\end{tabular}

Table 6: Mental and Psychological stress bound to come during the self-quarantine of any patients and the victims feel a lot of stress while the rescuers cope this stress through their positive behavior and $95 \%$ rescuers are agree that positive behavior plays a vital role in healing from COVID-19.

\begin{tabular}{|c|c|}
\hline \multicolumn{2}{|c|}{ What kind of positive behavior you adopt? } \\
\hline & Percentage \\
\hline Exercise & 27.5 \\
\hline Prayer & 57.5 \\
\hline Book Reading & 5.0 \\
\hline Social Media & 10.0 \\
\hline Total & 100.0 \\
\hline
\end{tabular}

Table 7: Various rescuers adopt various techniques of positive behaviors during their selfquarantine. As $57.5 \%$ rescuers do prayers, $27.5 \%$ do various exercises, $10 \%$ use social medial and only $05 \%$ do book reading to practice the positive behavior.

\section{Discussion}

As the first two cases were confirmed on $25^{\text {th }}$ February, 2020 in Pakistan, the Punjab Emergency Service, took the initiative to start a coronavirus patient shifting service from home to hospital. The first step in this regard was the establishment of Corona Rescue Helpline (1190) to provide the free of cost services to the public who were in a state of threat 
and terror. The staff of Punjab Emergency Service, Rescue 1122 started its services after adopting all the precautionary measures/standard PPE including gloves, face mask, gown, shoe cover, head cover and goggles etc. but unfortunately still the life threat was on.

The first SARS-CoV-2 positive case among the healthcare professionals of Punjab Emergency Service, Rescue 1122 was found on $25^{\text {th }}$ February, 2020 and from there 40 number of employees were infected out of approximately more than 13thousand employees who were performing their professional duties at pandemic. The healthcare professionals around the world are performing exemplary services during this outbreak. Overall, the infection rate in healthcare professional was $1.1 \%$ in a study at Wuhan. However, another study states the rate of infection among the paramedical staff at a high level of 3.8\% (Yasmin et al., 2020). This study shows that the overall median age of the employees of Punjab Emergency Service is 2635 years. There is a similarity in the age groups of health professionals between Rescue 1122 and the rest of the world as they are from the younger age groups that is also evident from several studies performed in China (Bi et al., 2020; Liu et al., 2020; Ran et al., 2020). And another study that was performed in Washington but the results were the same. While the paramedical staff of United States was at 42 years of median age when they were infected by the COVID-19 outbreak (McMichael et al., 2020). Majority of the Rescue 1122 employees had not any other pre-existing comorbidities i.e. kidney pain $(2.5 \%)$, cardiac disease $(0 \%)$, diabetes(0\%), lungs disease (0\%)etc (Hughes, 2020). The same level of health between healthcare professionals are the world. After their quarantine period the majority of the infected employees had various kind of experiences/views as they are of the view that separated quarantine (98\%) was the leading cause in the healing process, while positive behavior (95\%) was also very important during their healing process (Chou et al., 2020). The professional knowledge (82.5\%) and skills (85\%) about coronavirus disease, learned at Punjab Emergency Services also helps the rescuers to recover quickly. Also the peer's support (70\%) is the fourth leading cause in view of the rescuers that is essential to get motivational approach. The current trend is may be due to the younger mean age of the employees which again shows the identical observation of recent corona infection trends among the healthcare professionals. High Fever/Temperature (75\%), Sore Throat (75\%), Cough (68\%), and Muscle Pain $68 \%$ etc, were the common symptoms among the employees of Rescue 1122 . This study also found that majority of the employees 39 (97.5\%), had no previous fatal medical history (Chou et al., 2020).

\section{Conclusion}

The study identifies socio-economic aspects that the positive behavior, separate selfquarantine, peers support, same eating \& sleeping habits, professional knowledge \& skills were the key factors in the rapid healing process of the rescuers.

\section{References}

Ali, I., Shah, S. A., \& Siddiqui, N. (2020). Pakistan confirms first two cases of coronavirus, govt says "no need to panic". DAWN. COM, February, 26.

Bi, Q., Wu, Y., Mei, S., Ye, C., Zou, X., Zhang, Z., . . . Zhang, T. (2020). Epidemiology and Transmission of COVID-19 in Shenzhen China: Analysis of 391 cases and 1,286 of their close contacts. MedRxiv.

Chou, R., Dana, T., Buckley, D. I., Selph, S., Fu, R., \& Totten, A. M. (2020). Epidemiology of and risk factors for coronavirus infection in health care workers: a living rapid review. Annals of internal medicine, 173(2), 120-136. 
Hughes, M. M. (2020). Update: characteristics of health care personnel with COVID-19United States, February 12-July 16, 2020. MMWR. Morbidity and mortality weekly report, 69.

Liu, M., He, P., Liu, H., Wang, X., Li, F., Chen, S., . . Li, C. (2020). Clinical characteristics of 30 medical workers infected with new coronavirus pneumonia. Zhonghua Jie he he huxi za Zhi, 209-214.

MALIK, S. A., \& Javed, A. (2020). Forecasting unusual trend of covid-19 progression in pakistan. McMichael, T. M., Currie, D. W., Clark, S., Pogosjans, S., Kay, M., Schwartz, N. G., . . Lukoff, M. D. (2020). Epidemiology of Covid-19 in a long-term care facility in King County, Washington. New England Journal of Medicine, 382(21), 2005-2011.

Novel, C. P. E. R. E. (2020). The epidemiological characteristics of an outbreak of 2019 novel coronavirus diseases (COVID-19) in China. Zhonghua liu xing bing xue za zhi= Zhonghua liuxingbingxue zazhi, 41(2), 145.

Ran, L., Chen, X., Wang, Y., Wu, W., Zhang, L., \& Tan, X. (2020). Risk factors of healthcare workers with coronavirus disease 2019: a retrospective cohort study in a designated hospital of Wuhan in China. Clinical Infectious Diseases, 71(16), 2218-2221.

Yasmin, R., Parveen, R., Al Azad, N., Deb, S. R., Paul, N., Haque, M. M., . . A Azad, S. (2020). Corona Virus Infection among Healthcare Workers in a COVID Dedicated Tertiary Care Hospital in Dhaka, Bangladesh. Journal of Bangladesh College of Physicians and Surgeons, 43-49. 